International Journal of Learning, Teaching and Educational Research

Vol. 16, No. 11, pp. 28-44, November 2017

https://doi.org/10.26803/ijlter.16.11.2

\title{
Factors Influencing the Poor Academic Performance of Learners with Vision Impairment in Science Subjects in Kgatleng District in Botswana
}

\author{
Joseph Habulezi, Kefilwe P J Batsalelwang and Nelly M Malatsi \\ University of Botswana \\ Gaborone, Botswana
}

\begin{abstract}
This study employed qualitative research design. The main purpose was to determine factors that influence the poor academic performance of learners with vision impairment in science subjects at a senior secondary school in Botswana. Using purposeful sampling, 14 learners and 5 teachers were selected for the study. Data collection involved interviews, observation and document analysis. The findings revealed that multiple factors influence the poor performance of learners with vision impairment. The factors include shortage of human and material resources, teaching methods, teacher and learner attitudes. It is very clear from the findings that learners with vision impairment are experiencing challenges in learning science that are a result of deficient pedagogical practices, shortage of specialised teachers of science and material resources. The study, therefore, recommends intensive review of human resource deployment policies and improved monitoring and evaluation of inclusive education practices in schools if learners with vision impairment are to achieve the desired outcomes.
\end{abstract}

Keywords: Academic performance; science subjects; learners; vision impairment.

\section{Introduction}

Unsatisfactory academic performance of learners with vision impairment in science subjects has been pervasive at schools in Botswana. The Government of Botswana (2015) and United Nations Educational, Scientific and Cultural Organisation (UNESCO) (2015) report the declining academic performance in the country. The Botswana Daily News (2017) quoted the Minister of Basic Education, Dr. Unity Dow, reporting in parliament that the results for learners with special educational 
needs are not satisfactory. Government, though, has been working very hard to facilitate improved outcomes for all learners by addressing issues of quality, relevance, access, equity and accountability across the entire education sector (Government of Botswana, 2015).

Table 1: Performance of learners who use braille in science subjects

\begin{tabular}{lccccccc}
\hline Year & $\begin{array}{l}\text { \# of learners } \\
\text { sat for exam }\end{array}$ & $\begin{array}{l}\text { number } \\
\text { passed }\end{array}$ & $\begin{array}{l}\text { number } \\
\text { failed }\end{array}$ & pass \% & fail \% & $\begin{array}{l}\text { credit } \\
\text { pass \# } \\
\text { (A-C) }\end{array}$ & $\begin{array}{l}\text { quantity } \\
\text { pass \# } \\
\text { (A-E) }\end{array}$ \\
\hline 2016 & 9 & 0 & 9 & 0 & 100 & 0 & 0 \\
2015 & 11 & 1 & 10 & 9 & 91 & 0 & 1 \\
2014 & 8 & 2 & 6 & 25 & 75 & 0 & 2 \\
2013 & 6 & 2 & 4 & 33 & 67 & 0 & 2 \\
2012 & 5 & 1 & 4 & 17 & 83 & 0 & 1 \\
2011 & 4 & 1 & 3 & 25 & 75 & 0 & 1 \\
2010 & 3 & 1 & 2 & 33 & 67 & 0 & 1 \\
\hline
\end{tabular}

Source: Special Education Department, 2017

\section{The nature of science}

Scientific ingenuity is strongly linked to visual imagination and this is why within the world of science, numerous images cross science domains at all levels of practice (Maguvhe, 2015). This is why learners are generally exposed to visual displays in text books, teacher presentations and other multimedia materials (Jones, Minogue, Oppewal, Cook \& Broadwell, 2006). As a consequence, the capability of learners to infer and comprehend the representations has become more and more significant in education. In addition, science learning allows learners to gain problem-solving competency, experience inquiry activities, simulate their own thoughts and find the connection of science with everyday life.

\section{Science versus learners with vision impairment}

In learners with vision impairment, conceptual development and abstract thinking appear to be delayed by the absence of graphical stimulus or imageries; cognitive development occurs more slowly and standards for chronological age groups are void (Fraser \& Maguvhe, 2008). The fact that the greater parts of science representations are visual, learners with vision impairment frequently face educational challenges. This scenario emanates from the fact that most general education classroom teachers lack the appropriate teaching and learning strategies for learners with vision impairment. The consequent practices are text book science pedagogies which do not favour learners who have sight problems.

In addition to the foregoing, (Beck-Winchatz \& Riccobona, 2008; Moreland, 2015), majority of the general education classroom teachers find it difficult to teach learners with vision impairment because they have negligible experience and 
embrace rigid views as regards to the abilities of learners with vision impairment. There also seems to be a large gap between teachers' perspectives about what learners are able to do and the availability of teaching and learning resources to help the learners realize their full potential. In short, McCarthy (2005) and Pressickkilborn and Prescott (2017) are of the view that learners with vision challenges are deprived of the opportunities to experience science even when there is substantiation that hands on-science approach yields better results for learners who have vision challenges. Essentially, learners with vision impairment have cognitive abilities equivalent to their peers and can equally become scientists. With the right methods and assistive technology, the science learner who is visually impaired, can learn and do the same assignments as other science learners (Beck-Winchatz \& Riccobono, 2008).

\section{Science curriculum for learners with vision challenges}

The science curriculum offered should be broad, balanced and accessible to provide the maximum educational opportunities possible for all its learners regardless of the diversity or complexity of their needs (Habulezi \& Phasha, 2012). Although science education for those who are visually impaired is very challenging and expectations are low, learners who are visually challenged perform very well or moderately depending on the learning support provided. Every piece of material, instrument or text can somehow be modified with creativity, skill and tenacity to make it accessible for those who have vision impairment. Employing appropriate instructional methods, accommodations, adaptations, use of innovative forms of assistive technology, having a positive mind set and embracing all learners regardless of their circumstances helps learners excel in their own right (Ayiela, 2012).

\section{Use of concrete materials and tactile graphics}

Science subjects are highly painterly in nature and frequently utilise visuals to convey significant materials, bestowing supplementary difficulty for learners with vision impairment (Smith \& Smothers, 2012). The use of concrete material and tactile graphics largely benefit all learners because the practice increases computation accuracy, helps them reason and solve problems (Hansen et al., 2016; Hatlen, 1996). Manipulatives further offer children with vision impairment concrete experiences to help them understand their environment and learn concepts parallel to sighted peers in the classroom setting (Saracho, 2012). It is, therefore, of necessity for teachers of learners with visual deficits to not only provide concrete objects and tactile graphics but also teach learners how to read and make sense of concrete materials and tactile graphics in science subjects (Zebehazy \& Wilton, 2014).

In order to teach learners to be effective in the management and understanding of a diversity of manipulatives and tactile graphics, teachers ought to use a sequence for introduction of the materials (Koenig \& Holbrook, 2010). Teachers should first

present learners with opportunities to handle real objects, transition to the use of models and finally implement two dimensional representations. The effective 
interpretation of manipulatives and tactile graphics needs knowledge of spatial and geographic concepts and strategies for exploring and interpreting the displays (Mastropieri \& Scruggs, 2010; Kapperman et al., 2000; Claudet, 2014; O'Day, 2014). Finally, after all tactile observation experiences, teachers should help learners connect concrete objects, tactile graphics and abstract.

\section{Aims of the study}

The aims of the study were to investigate the factors that influence the poor academic performance of learners with vision impairment in science subjects at the school and to propose ways of improving the academic performance of learners. The study used the following research questions: What factors affect the academic performance of learners with vision impairment in science subjects at the school? How can the school improve the academic performance of the learners in science subjects?

\section{Method}

The study employed a qualitative approach because it is concerned with the exploration of problems and this eventually leads to the understanding of a given phenomenon (McMillan and Schumacher, 2014); in this case, factors that influence the poor academic performance of learners in science subjects

\section{Participants and research setting}

An inclusive senior secondary school with a special education unit catering specifically for learners with vision impairment, (at least up to 2013 when the inclusive education policy came into effect), was used as a research site, following permission the Ministry of Basic Education granted the regional education office to conduct the study at the school. This research was part of the wider research carried out during the Inclusive Education workshop under the North/South collaboration inclusive research project.

Multi stage sampling technique was used to select the sample for the study. The first stage involved purposive selection of 14 learners with vision impairment (out of a total of 28 learners) who were taking sciences. The learners, whose age range was 16-21 years, were then stratified based on their gender (6 males \& 8 females). Further, volunteer sampling procedure was used on the special education and general education teachers. Three female and two male teachers were selected and their age range was 29 - 44. In total, the study had 19 participants (8 males and 11 females).

\section{Instruments}

Interviews, observation and document analysis were used to collect the data. Interviews lasted for approximately 20 - 40 minutes, depending on the interviewees' willingness to talk. In-depth interviews were asked in an open-ended manner. The semi-structured interview permitted the researchers to control the interview. 
School authorities granted access to documents which were provided for analysis to supplement data collected by means of interviews and observation. The documents included inspection reports, special education termly and annual reports, assessment reports and items, scripts from learners and attendance registers. Week long observations were done in two classes of the 6 which had learners with vision impairment. The two teachers of the classes volunteered to be observed.

\section{Data collection process}

A pilot study was conducted to trial data collection instruments with the aim of determining their suitability. For a pilot study, 6 participants who were not among the participants for the research ( 3 males and 3 females) were interviewed. The results of the pilot study led to the addition of school documents which include assessment items, inspection and departmental reports. Before data collection, two meetings were held with the participants to address ethical issues and share the purpose of the research. Participants were urged to seek clarifications on anything concerning the research. Permission was obtained to record the conversations using digital voice recorders and participants were assured that the recorded data would be kept confidentially.

\section{Data analysis}

Data were transcribed verbatim. When transcriptions were ready, they were repeatedly read to gain familiarity with the data (Creswell, 2007). As a way to corroborate the interview data, it was compared with the data from observations and document analysis. The following stage involved categorising data according to the meanings generated. This was followed by relating categories and subcategories in order to provide explanations with regard to the poor academic performance of learners with vision impairment in science subjects which culminated into the explication of data on the studied subject.

\section{Results}

From the interviews conducted with participants, observations made and information from the documents, it was evident that there are multiple factors influencing the poor academic performance of learners with visual deficits at the school. This is against the mammoth efforts and government resources invested in the education of learners with vision impairment. Below are the themes that emerged as factors influencing the poor academic performance of learners at the school. 


\section{Large class sizes}

The records analysed yielded results as tabulated in the table below.

Table 2: Class enrolments for 6 classes with learners with vision impairment

\begin{tabular}{ccccc}
\hline Class & Form & \# of VI learners & \# of sighted learners & Total \\
\hline 1 & 5 & 3 & 38 & 41 \\
2 & 5 & 4 & 35 & 39 \\
3 & 5 & 3 & 38 & 42 \\
4 & 4 & 3 & 38 & 41 \\
5 & 4 & 2 & 35 & 37 \\
6 & 4 & 4 & 36 & 40 \\
\hline
\end{tabular}

Source: Pastoral records (class registers)

The attendance registers perused indicated the above class enrolments for the various classes. The registers confirmed interview results from three of the teachers interviewed who complained of the large class sizes that translate into huge teaching loads. When the senior teacher was asked about the number of learners in the classes, she indicated that the issue was beyond their control. Authorities from Ministry headquarters would just refer learners and instruct the school to admit and the school has no power to deny a child a place.

\section{Shortage of human and material resources}

The two Biology classes observed had teachers by themselves handling all the learners. In one class, when experiments were being carried out the teacher told learners with vision impairments:

Go to the Special Education Department and read

The statement above resonated with complaints from three learners with vision impairment who stated that every time there are experiments being done in the laboratory or when the class is writing notes from the chalk board, we are told to go to the Special Education Department and do something else. Asked what the teacher would do to compensate for the missed experiment, she stated that learners who are blind do not carry out experiments, instead, they sit for paper 4 , alternative to practical. The teacher further said:

The learning support workers are supposed to be working with us during practical sessions as practical assistants but Special Education Department claims there is a shortage of learning support workers.

In an interview with a special education specialist teacher, we learnt that there was only one science special education trained Biology teacher in the Science Department trained to teach learners who have vision impairment. She stated that:

The officers at Teaching Service Managment are missing a point, when specialist teachers graduate; they send them anywhere in the name of inclusive education and 
send ordinary teachers here. Areas like VI and HI are specialised areas and need trained teachers. Imagine all those twenty something teachers in the Science Department, I am the only trained special education teacher. No one for Chemistry and Physics. In addition I have 4 classes to teach.

The excerpt above coincides with the information obtained in the special education annual reports that there is a shortage of specialist trained science teachers. Some known science trained special education teachers refuse to be deployed at the school because they claim there is too much work in special education and besides, they are already enjoying scarce skill allowance as teachers of science.

On the part of learning and teaching resources, 8 of the 14 learners interviewed complained of the shortage of assistive technology. One learner stated that:

They do not buy the equipment we need but buy what they want. How can they buy stacks and stacks of braillon paper when what we need is zytex or ordinary braille paper, adapted computers, CCTVs, digital voice recorders (meant for the VI, not for journalists), ...

One of the specialist teachers echoed similar sentiments that:

Government has bought a lot of materials that are not really relevant. You know this merging of special education and guidance and counselling is not working for us. How can they appoint a person from a related field to be in charge of special education? This is the result, buying wrong stuff and failing to defend order requests at the tender board because they do not know.

The records also indicted that the shortages of material resources were artificial as government allocates money for items but during the procurement stage, delays due to bureaucracy and lack of justification for the items would work against the department. One teacher was quoted saying:

The government is very transparent in its purchase procedures, when our representatives from related fields fail to justify why we have to buy this or that, things are not bought.

A check at the Special Education Department revealed that there were a lot of perkins braillers, (mostly malfunctioned), 3 thermoforms, 3 CCTVs, a few scientific talking calculators, 2 braille embossers, two old adapted computers. Learners were observed sharing a talking calculator during a test and others taking turns in using the three CCTVs. There were neither prescribed books in braille nor in large print despite the sighted learners being given all the prescribed books in each subject.

\section{Attitudes of learners and teachers}

When asked what they think are the factors influencing the poor performance of learners in science subjects at the school, 11 of the learners interviewed frankly stated that sciences were too difficult for them because they had a lot of diagrams. Further probing revealed that they have a lot of past examinations tactile graphics 
to use during the lessons and there are no teachers to tactile orientate the learners to these diagrams which are not tailored towards the topic being taught. One of the learners said:

You know sir, every time a teacher comes in class talks about some diagrams in a book or on the chalk board, they first discuss then later, will say eeh special ed learners, after the lesson go to Special Ed so that they search for diagrams on this topic for you from past exam papers, ok! Because of some of these statements and teachers remembering that we are also in their classes upon seeing us in classes, I hate any science subject. After all, no special education learners who are totally blind pass sciences.

The excerpt above suggests a negative attitude by the learners towards science subjects. On the other hand, 2 of the 5 teachers interviewed indicated that it was not their responsibility to teach learners who are blind outside the normal scheduled lessons. One of them said:

Look, there are people who are paid scarce skill allowance to teach special education learners. We are all not here for them, in fact given a chance, I wouldn't want them in my class because they are a bother. You have to prepare work twice and wait for their work to be transcribed ... no man!

The statement above was understood to be negative attitude from the teacher. The records also showed that in 7 of the report books, marks for special education learners were not recorded yet for the previous term. Class teachers referred all queries to the Special Education Department. A member of the Special Education Department retorted:

These teachers and their attitude! What will it take for them to change and treat all learners equally? The book is here, all scripts were submitted to all teachers and signed for.

The statement above also suggests negative attitude that has been going on in the school about learners with vision impairment.

Inadequate adaptation and modification of teaching and learning resources The learners complained of the fatigue they go through when trying to decipher meaning from the many tactile diagrams found in science assessment items. They claimed the sensation on their fingertips sometimes lets them down as they have to battle the different textures of paper; the question paper on ordinary braille paper which is a bit hard and the diagrams on soft zytex paper. One learner emotionally said:

Imagine in one of the science papers with 60 questions, 47 of the questions have diagrams you are not even familiar with. Even some of the questions that one can answer without a diagram will have a diagram.

Similarly, one learner who is partially sighted complained that a facility where she was assessed from recommended a font of 24 but teachers were just enlarging print 
anyhow using the photocopying machine. Sometimes the font was better but other times not. Rarely were the notes Brailled for braille users in most science subjects except Biology. Most of the times, fellow learners had to dictate the notes to learners with vision impairment.

\section{Teaching methods}

Government of Botswana (2015) whole school inspection report reads in part: The teaching methodologies the majority of the teachers employed were teacher centred and as such did not promote cooperative and practical learning (p.12). ... Learners were not actively involved in the learning process since they rarely demonstrated knowledge and understanding of what they learnt.

The preceding excerpt confirmed the findings from the observations where one teacher spoke in a low voice; neither read nor described what she had written on the chalk board for the sake of learners with vision impairment. The writing was illegible as she wrote small letters in cursive. While she had teaching aids for the sighted learners, there were no embossed diagram for learners with visual deficits. Three of the teachers interviewed claimed they did not know the learning and teaching methods for learners with vision impairment. To the contrary, special education departmental reports indicated that a workshop was held for teachers on the same. In addition, induction workshops are held every year for new teachers in the school.

\section{Large teaching loads}

The five teachers interviewed were all concerned over the large teaching loads that teachers carry. They contest that the guidelines being followed were prepared when the class enrolments were favourable. One of the teachers stated that:

You know, our population was very small and we could afford something like 25 to 35 learners in a class. We did not even have as many special education learners like we do today. Maybe only one or two special education learners in a year. But this time, we are talking about 30 learners with special educational needs in the school and an average of 43 learners per class.

Some comments from teachers suggested that the administrators heading schools with special education units should be trained in the area so that they can easily articulate the issues concerning special education.

This was meant to indicate that management and the regional office do not represent the special education area well because they were not trained in special education. 


\section{Discussion}

The academic performance of learners with vision impairment in science subjects at the school is faced with a lot of factors. The attainance of viable institutional improvements needs thorough understanding of the factors that robustly combine to create institutional failure. This section therefore discusses some of the factors identified during the study.

\section{Large class sizes}

Hattie (2006) cites McGiverin, Gilman, and Tillitski (1989) who conducted a metaanalysis of 10 studies of Indiana's Prime Time project, a longitudinal study which aimed to reduce class size to 14 in 24 Year 1-3 classes. They reported that Year 3 learners, who had been in smaller classes for 2 years had significantly higher achievement test scores than did learners in larger classes. The significant academic achievement in smaller classes is the intended destiny the Ministry of Basic Education, Botswana would want to achieve. It laid guidelines regarding the reduction in the number of learners in the classes that had learners with vision impairment. School authorities are therefore expected to work in line with the national guidelines.

In Botswana, one learner with vision impairment is equal to four sighted learners. So, to have 38 sighted learners and 3 learners with vision impairment in a class means that the class had an enrolment of 50 learners which is just too much. These findings are similar to Koh and Shin's (2017) observation that class sizes are other demands for teachers that affect their feelings and performance in inclusionary practices. In a case like this one, the rate of learning support is compromised as reduced class enrolment is meant to maximise the support to learners who are disadvantaged (Bruwiler \& Blatchford, 2011; Njue, Aura \& Komen, 2014). It is worth noting that the school authorities make frantic efforts to reduce the number of learners in classes which learners with vision impairment are allocated. The largest of the classes where learners with vision impairment were had 42 learners. There are however, some classes without learners with vision impairment that had class enrolments of 46. School authorities explained they experienced challenges in reducing the number of learners because the transition rate from junior to senior secondary school has been increasing to give all Batswana children a chance of being educated as the country is marching towards being an educated and informed nation.

\section{Shortage of human and material resources}

The Botswana Government awards scarce skill allowance to Science, Mathematics and Special Education teachers as a way of retaining and motivating them. Despite the incentive, some science teachers choose to teach in the mainstream school because they would still receive the scarce skill allowance. The teachers' move leaves a gap in the number of special education trained science teachers; hence the shortage. On the other hand, mainstream science teachers outnumber special education trained science teachers. This paints a picture that there is shortage of 
staff when in fact; the teachers are according to the staff establishment register. What is required, therefore, is to deploy more special education trained teachers to the school. Besides, some teachers during the interview confessed that they do not have requisite skills in teaching learners with vision impairment.

The lack of skills of most of the teachers teaching learners could be one of the contributing factors to the learners' poor academic performance in science subjects (Mphale1 \& Mhlauli1, 2014). However, according to Koh and Shin (2017), barriers and concerns of this nature are frequent even in countries like United States of America. Most frequent in their study were inadequate and insufficient training for teachers to help them teach in inclusive classrooms and lack of resources for effective inclusive education practices.

One of the concessions in the education of learners with vision impairment is providing aides or other special arrangements to undertake teaching, learning or assessment tasks (Fraser \& Maguvhe, 2008; Capps, Kingsley, Kuo \& Roecker, 2014). The provision is meant to increase support because some learners may require one on one teaching. This is common occurrence in practical subjects like Art and Sciences. In the two classes observed in this study, there were no learning support workers to act as experiment aides. Instead, learners with vision impairment were asked to go and read at the Special Education Department. This denied the learners a learning opportunity and would contribute to their poor performance in science subjects. Classroom support helps to increase learner participation and academic achievement. Use of special needs teachers and other learning support workers would bring some needed additional resource to augment on teachers' efforts in the classrooms. At the time of this study, there was only one learning support worker who was overwhelmed by demands of the tasks in the Special Education Department. During debriefing though, it was observed that the number of learning support workers had increased to four, which is a good move except the high learner enrolments would demand more. The school has basic assistive devices and instructional technology that teachers and learners use. These include CCTVs (3), Photocopying machine, talking calculators, digital voice recorders, tape recorders, embossing kits, braille and swell paper, embossers, thermoforms, perkins braillers, slates and styluses to mention but a few.

There were a few models found in the Special Education Department. During class observations, neither models nor concrete objects were used despite their importance in increasing computation accuracy, helping learners to reason, solve problems and offering learners concrete experiences to help them understand their environment (Hatlen, 1996; Saracho, 2012). There is an abundance of tactile graphics mostly from past examinations. These are not serving the learners well because they are not topic specific. Besides, the science teachers do no tactile observations to help the learners understand the materials. Learning support workers give learners embossed diagrams which are meaningless because no one takes the learners 
through the embossed graphics to make sure the learners understand. This practice has a bearing on the learners' performance.

\section{Attitudinal barriers}

From the interviews conducted with the learners, their poor performance in sciences is partly due to self-prophecy fulfilment. The learners are resigned to the belief that learners with vision impairment do not pass science subjects. Additionally, the many diagrams that characterise science assessment tasks frustrate the learners that they have some negative attitude towards the subjects. Teachers' lack of inclusive preparations that result in failure to arrange for embossed diagrams prior to meetings with the learners encourages the learners' negative attitude towards sciences.

Teachers, too, have their own attitude towards the teaching of learners with vision impairment. The fact that Government of Botswana awards scarce skill allowance to special education teachers makes some teachers feel that the onus of teaching learners with special educational needs is for teachers receiving scarce skill allowance. The mainstream teachers' attitude therefore falls short of a positive one. Some of their teaching sessions are devoid of a sense of care, responsiveness, adaptation, cohesiveness and synergy that bonds people together (Landberg, Kruger \& Swart, 2016); hence, the learners' poor academic showing in science subjects.

\section{Modification and adaptation of teaching and learning materials}

Science teaching and learning content as well as assessment tasks are inundated with graphic representations that are too much for learners with vision impairment during examinations. Learners are sometimes fatigued in an effort to explore the diagrams which they rarely understand and eventually perform poorly. Some of the diagrams included in assessment tasks have no bearing on the answering of questions and these just increase material for reading when in fact the effort should be to reduce it. Njue, Aura and Komen (2014) advise that individual differences of the learners should be put into consideration and the teachers should therefore choose materials which maximally benefit individual learners. The photocopying of learners' work without being font specific is dreadful and would destroy learners' sight or create other problems to the learners. Effort should be made to avail recorded, brailled or enlarged teaching and learning resources to promote equal access to education for all learners.

\section{Teaching methods}

The No Child Left Behind Act of 2001 (NCLB) recognise accountability actions including annual assessment of learners in the technical areas such as sciences. The teacher centred teaching methods that do not accommodate all learners, (Habulezi, Molao, Mphuting \& Kebotlositswe, 2016), are counterproductive and detrimental to learners' performances. The Ministry of Basic Education's (2015) findings in the inspection report and findings from the observations during this study leave a lot to 
be desired. Teachers are assets, rich resources of information and support. Therefore, they need to be responsive, creative, accommodative and inclusive in their routine facilitation of classroom activities for the benefit of all learners. In the case of learners with vision impairment, pre or post lesson sessions would be appropriate to compensate for the missing incidental information acquisition and to promote parity in classroom participation.

Landberg, Kruger and Swart (2016) advise that teachers should encourage critical thinking, argumentation, reflection and action on the part of learners in the learning situation. In addition, Rose and Meyer (2002)'s three principles of universal design of learning, (multiple means of representation, multiple means of action and expression, multiple means of engagement), hold great potential to establish truly accessible learning environments for all that can improve learners' performance.

Holbrook and Koenig (2010) agreed that in the absence of vision, it was important to give learners sensory training to the remaining senses like the senses of touch and hearing so that they might be used as sources of information. To the contrary, the results in this study indicate that learners were not being tactile orientated to the embossed diagrams given to them. Further, some teachers neither read nor described what they wrote on the chalk board. This does not compliment to the missing incidental learning other learners with sight enjoy. Besides, the tactile diagrams presented to the learners with vision impairment were not topic tailored but related past examination diagrams. The practice denies learners equal and fair opportunity to access teaching and learning materials. In some instances, learners with vision impairment were sent to the Special Education Department to read while the learners with sight carried out experiments which augmented on the theory they had learnt, but alas for learners with vision impairment, it is an opportunity of learning missed for ever.

\section{Large teaching loads}

Landsberg, Kruger and Swart (2016) observed that teachers are overwhelmed by workloads that over stretch them such that they even fail to implement intervention strategies or support stakeholders. The foregoing observations were reflected in teachers' comments in this study where teachers were unable to employ intervention strategies due to the increase in enrolments and other demands in their daily routine operations. Further, the Biology special education teacher had four classes to teach in addition to her special education duties that include brailling, remediation, consultations and transcription among others. Two science special education teachers concentrated on their duties in the mainstream school and did not want to associate themselves with the special education duties because they still enjoyed scarce skill allowance as science teachers. Understanding of the important role special education teachers play in supporting learners and other stakeholders would be very helpful in improving service provision to the learners and consequently improve learners' performance in the subjects concerned. Clear 
policies and awareness campaigns would be very helpful in this regard (Mutanga \& Walker, 2017).

\section{Conclusion}

Learners with vision impairment are facing challenges in learning science due to multiple factors. Even well-meaning efforts if not properly handled retrogress learner performance. The awarding of scarce skill allowance to special education teachers led to some teachers who were not awarded the same to be reluctant in helping learners with vision impairment. Objectionable teacher and learner attitudes also play some part including pedagogical practices that are not really tailored to meet individual learner needs. Although there are tolerable human and material resources, the resources are not good enough to yield the desired academic performance of the learners. Positive efforts in some instances are abound, but what should be borne in mind is that all schools, even the most successful ones, have occasional slumps in performance to fluctuating gradations. This is occasionally linked to shifts in learner composition, changes in the external environment and issues of staff turnover.

\section{Recommendations}

Intensive intervention measures targeted at improving learners' academic performance in science subjects are suggested. These should include enhanced teaching and learning activities, deployment of more special education trained science teachers, learning support staff and acquisition of specialised equipment. Further, continued public sensitization on positive inclusive education practices would be handy in the quest for excellency.

\section{References}

Ayiela, O. J. (2012). Factors affecting KCPE performance of learners with hearing impairments in special schools in selected counties, Kenya. Unpublished thesis, Kenyatta University.

Babbie, E., \& Mouton, J. (2010). The practice of social research. Cape Town: Oxford University Press.

Beck-Winchatz, B., \& Riccobono, M. (2008). Advancing participation of blind students in Science, Technology, Engineering and Mathematics. Advances in Space Research, 42, 1855-1858. Doi: http://dx.doi.org/10.1016/j.asr.2007.05.080.

Botswana Daily News, (2017, March 7) Special Education results not satisfactory. BOPA: Gaborone.

Bruwiler, C., \& Blatchford, P. (2011). Effects of class size and adaptive teaching competency on classroom processes and academic outcome. Learning and Instruction, 21 95-108. https://doi.org/10.1016/j.learninstruc.2009.11.004.

Capps, K., Kingsley, K., Kuo, K. Y., \& Roecker, L. (2014). Inquiry-based education for students with visual impairment. Deborah L. Rooks-Ellis: Orono.

Claudet, P. (2014). Designing tactile illustrated books. Journal of Blindness, Innovation and Research. 4, (1). Doi: http://dx.doi.org/10.5241/4-52 .

Creswell, J. W. (2007). Research design, qualitative, quantitative and mixed methods approaches. Thousand Oaks, CA: Sage Publications. 
Dalton, E. M., Mckenzie, J. A., \& Kahonde, C. (2012). The implementation of inclusive education in South Africa: Reflections arising from a workshop for teachers and therapists to introduce Universal. Design for Learning. African Journal of Disability 1(1) 13. Doi: 10.4102/ajod.v1i1.13.

Dubnick, M. (1994). Response to David Wohlers' presentation: The visually-impaired student in Chemistry. Access to scientific data by persons with visual disabilities. In Egelston-Dodd, J. (Ed.), A future agenda: Proceedings of a working conference on science for persons with disabilities. IA: University of Northern Iowa, pp. 68-70.

Government of Botswana, (2015). Whole school inspection report, Molefi Senior Secondary School. Kgatleng Education Region. Ministry of Basic Education: Gaborone.

Fraser, W. J., \& Maguvhe, M. O. (2008). Teaching life sciences to blind and visually impaired learners. Educational Research 42(2) 84-89.

Doi: https://doi.org/10.1080/00219266.2008.9656116

Habulezi, J. \& Phasha T., N. (2012). Provision of learning support to learners with visual impairment in Botswana: A Case Study. Procedia - Social and Behavioral Sciences, 69(24) 1555-1561. Doi: http://dx.doi.org/10.1016/j.sbspro.2012.12.098.

Habulezi, J., Molao, O., Mphuting, S., \& Kebotlositswe M. K. (2016). Inclusive education and challenges of providing classroom support to students with blindness in a general education classroom at aschool in Botswana. International Journal of Learning, Teaching and Educational Research, 15(1) 30-41.

Hansen, E. G., Liu, L. Hakkinen, M. T., \& Darrah, M. (2016). Designing innovative science assessments that are accessible for students who are blind. Journal of Blindness, Innovation and Research, 6 (1). Doi: http://dx.doi.org/10.5241/6-91.

Hatlen, P. (1996). The core curriculum for blind and visually impaired students, including those with additional disabilities. RE:view, 28(1), 25-32.

Doi: http://dx.doi.org/10.4135/9781483329253.n3.

Hattie, J. (2006). The paradox of reducing class size and improving learning outcomes. International Journal of Educational Research, 43 387-425.

Doi: http://dx.doi.org/10.1016/j.ijer.2006.07.002.

Holbrook, M. C., \& Koenig. A. J. (2010). Foundations of education: History \& theory of teaching children and youths with visual impairments. AFB Press: New York.

Jones, M. G., Minogue, J., Oppewal, T., Cook, M. P., \& Broadwell, B. (2006). Visualizing without vision at the microscale: Students with visual impairments explore cells with touch. Journal of Science Education and Technology, 15(5), 345-351. Doi: http://dx.doi.org/10.1007/s10956-006-9022-6.

Kapperman, G., Heinze, T., \& Sticken, J. (2000). Mathematics. In A. J. Koenig \& M. C. Holbrook (Eds.), Foundations of education: Instructional strategies for teaching children and youths with visual impairments (Vol. II, pp. 370-399). New York: AFB Press.

Koh, M., \& Shin, S. (2017). Education of students with disabilities in the USA: Is Inclusion the answer? International Journal of Learning, Teaching and Educational Research, 16(10)1-17. Doi: https://doi.org/10.26803/ijlter.16.10.1.

Landsberg, E., Kruger, D. \& Swart, E. (2016). Addressing barriers to learning. A South African perspective. (3rd ed). Van Schaik: Pretoria.

Maguvhe, M. (2015). Teaching Science and Mathematics to students with visual impairments: Reflections of a visually impaired technician. African Journal of Disability 4(1), 1-6. Doi: http://dx.doi. org/10.4102/ajod.v4i1.194. 
Mastropieri, M. A., \& Scruggs, T. E. (2010). The inclusive classroom: Strategies for effective differentiated instruction. (4th ed.). Upper Saddle River, NJ: Merrill.

McCarthy, C. (2005). Effects of thematic-based, hands-on science teaching versus a textbook approach for students with disabilities. Journal of Research in Science Teaching, 42, 245263. Doi: http://dx.doi.org/10.1002/tea.20057.

McMillan, J. H., \& Schumacher, S. (2014). Research in education: Evidence-based enquiry. (7th ed). Pearson: Boston.

Moreland, L. M. (2015). Science for visually impaired students and accessible technology. Theses, Dissertations and Capstones. Paper 978. Marshall University.

Mphale, L. M., \& Mhlauli, M. B. (2014). An investigation on students' academic performance for junior secondary schools in Botswana. European Journal of Educational Research, 3(3), 111-127. Doi: http://dx.doi.org/10.12973/eu-jer.3.3.111.

Mutanga, O., \& Walker, M. (2017). Exploration of the academic lives of students with disabilities at South African universities: Lecturers' perspectives. African Journal of Disability, 6(0), a316. Doi: https://doi. org/10.4102/ajod.v6i0.316.

Njue, S. W., Aura, L. J., \& Komen, Z. (2014). Braille Competency among learners with visual impairments: Methodology and learner preparedness factors in Thika and Meru Counties, Kenya. International Journal of Humanities and Social Science, 4(10) 109-116. Doi: http://dx.doi.org/10.5901/jesr.2014.v4n1p479.

No Child Left Behind Act of 2001, Pub. L. No. 107-110, 115 Stat. 1425 (2002).

O'Day, A. R. (2014). Proof reading the tactile graphic: The important last step. Journal of Blindness, Innovation and Research, 4(1). Doi: http:/ /dx.doi.org/10.5241/4-59.

Peters, S. (2004). Inclusive education: An EFA strategy for all children. World Bank: Washington, DC.

Pressick-kilborn, K., \& Prescott, A. (2017). Engaging primary children and pre-service teachers in a whole school Design and Make Day: The evaluation of a creative science and technology collaboration. Journal of the Australian Science Teachers Association, 63 (1).

Rose, D. H., \& Meyer, A. (2002). Teaching every student in the digital age: Universal Design for Learning. ASCD: Alexandria, VA.

Rose, D. H., \& Strangman, N. (2007). 'Cognition and learning: Meeting the challenge of individual differences', Universal Access in the Information Society, 5(4), 381-391.

Doi: http://dx.doi.org/10.1145/1102187.1102193.

Saracho, O. (2012). An integrated play-based curriculum for young children. Routledge: New York.

Smith, D. J. (1998). Inclusion: Schools for all students. Wadsworth Publishing Company: Albany, NY.

Smith, D. W., \& Smothers, S. M. (2012). The role and characteristics of tactile graphics in secondary Mathematics and Science textbooks in Braille. Journal of Visual Impairment and Blindness, 106(9), 543.

Doi: http://dx.doi.org/10.1111/j.1949-8594.1985.tb09639.x.

Special Education Department, (2017). End of term one departmental report. Molefi Senior Secondary School: Mochudi.

Wagner, B. V. (1995a). Guidelines for teaching science to students who are visually impaired. In Egelston-Dodd, J. (ed.), "Improving science instruction for students with disabilities: University of Northern Iowa, pp. 70-76. 
Wohlers, H. D. (1994). Science education for students with disabilities. In Egelston-Dodd, J. (ed.), A future agenda: Proceedings of a working conference on science for persons with disabilities. IA: University of Northern Iowa, pp. 52-64 Web Resources,

Doi: http://dx.doi.org/10.1007/s10209-006-0062-8.

UNESCO, (2015). Education for All 2015 National Review Report. Government printers: Gaborone.

United States Department of Education, (2007). 'No child left behind: Choosing a school for your child' viewed 07 June 2015, from http://www.ed.gov/parents/school/find/choose.

Zebehazy K. T., \& Wilton, A. P. (2014). Quality, importance and instruction: The perspectives of teachers of students with visual impairments on graphics use by students. Journal of Visual Impairment \& Blindness, 108(1), 5-16. 